\title{
VARIABILITY OF EJACULATE VOLUME AND SPERM MOTILITY DEPENDING ON THE AGE AND INTENSITY OF UTILIZATION OF BOARS
}

\author{
R. Savić ${ }^{1}$, M. Petrović ${ }^{1}$, D. Radojković ${ }^{1}$, Č. Radović ${ }^{2}$, N. Parunović ${ }^{3}$, M. Pušić ${ }^{4}$, \\ R. Radišić ${ }^{4}$
}

${ }^{1}$ University of Belgrade - Faculty of Agriculture, 11080, Belgrade - Zemun, Republic of Serbia

${ }^{2}$ Institute for Animal Husbandry, 11080, Belgrade - Zemun, Republic of Serbia

${ }^{3}$ Institute of Meat Hygiene and Technology, 11000, Belgrade, Republic of Serbia

${ }^{4}$ Institute of Science Application in Agriculture, 11000, Belgrade, Republic of Serbia

Corresponding author: savic@agrif.bg.ac.rs

Original scientific paper

Abstract: The main objective of this study was to evaluate the effect of age (A) and the intensity of the boars' utilization (s) on the phenotypic variability of ejaculate volume (VOL) and sperm motility (MO). The study included 274 ejaculates of Large White boars (LW). Boars were divided into six classes according the age when the ejaculate was taken (10-13, 14-17, 18-21, 22-25, 26-29 and $\geq 30$ months). Semen samples were analyzed during four seasons (spring, summer, autumn, winter). The intensity of the use of boars was seen as the impact of the group (class) of intervals between two successful collections (I; $\leq 5,6,7,8$, 9-10, 11-13, 14-21 days). Data processing was performed using the GLM procedure using the statistical package SAS 9.1.3 (SAS Inst. Inc., 2002-2003). Average values of VOL, MO, I, A, were: $178.94 \mathrm{ml}, 90.35 \%, 9.37$ days and 655.93 days. The effect of boars on both studied sperm traits was highly significant $(p<0.001)$. The volume of ejaculate varied under the influence of boar age $(p<0.001)$ and season $(p<0.01)$. The effect of I on VOL and MO was not significant $(p>0.05)$. Traits VOL and MO varied $(p<0.001)$ between boars which indicated the need for individual control of each of boars used for artificial insemination. The highest VOL was determined in boars at the age of 26 to 29 months, and the difference to the boars aged 10-13 months was $62.70 \mathrm{ml}(\mathrm{p}<0.001)$. No statistically significant differences in regard toVOL between boars older than 17 months (from class 3 to 6 ) were recorded. The highest differences between winter and spring period were determined in mean values of VOL $(32.15 \mathrm{ml} ; \mathrm{p}<0.01)$. In the winter period, boar ejaculate volume was lower than in the autumn $(-26.57 \mathrm{ml})$ and the difference determined was statistically significant $(p<0.05)$.

Keywords: pigs, boar, ejaculate volume, motility 


\section{Introduction}

In modern pig production, artificial insemination has completely suppressed the natural mating, so that the evaluation of quantitative and qualitative characteristics of ejaculate is a standard procedure in breeding technology. Rating quantitative and qualitative characteristics of semen has high economic importance to the pig breeders (Smital, 2010).

In populations of pigs which are under continuous selection program there is a tendency for the better utilization of boars, good production performance, which is reflected in the preparation of a large number of doses per ejaculate of optimal fertile ability. In addition to sperm concentration, semen volume and sperm motility determine fertility of doses produced per ejaculate. Motility is the most important trait that affects fertilization capacity of sperm (Feitsma, 2009). Rating motility of spermatozoa is the most important parameter of sperm (KunowskaSlósarz and Makowska, 2011).

Variability of ejaculate volume and sperm motility is influenced by various genetic and paragenetic factors. Properties of boar sperm vary under the influence of breed, age, season, intensity of use, and other factors (Stančić et al., 2003; Frangež et al., 2005; Okere et al., 2005; Wolf and Smital, 2009a; Wolf and Smital, 2009b; Kondracki et al., 2009; Smital, 2010; Kunowska-Slósarz and Makowska, 2011).

The aim of this study was to determine how age, intensity of use of boars and annual season affect the phenotypic variability of ejaculate volume and sperm motility.

\section{Material and methods}

The study included a total of 274 ejaculates from 6 boars of breed Large White (LW).

Ejaculates from boars grown under production conditions for a period of two years (October 2010 - September 2012) were examined. The data on the volume of ejaculate (VOL, ml) and sperm motility (MO \%) of boars were used. Ejaculate volume was measured with an accuracy of $\pm 10 \mathrm{ml}$, and sperm motility evaluation was performed by a subjective method, observing the native sperm sample under a microscope with a standard magnification (visual score). The average number of ejaculates per boar was 45.67, and boars with less than five ejaculate were excluded from the analysis. Ejaculates with VOL below $50 \mathrm{ml}$ or MO less than $70 \%$ were not included in the study. At each taking of ejaculate collection) the age of the boar was recorded, and the average age was calculated as the average of all ages at the individual collections of boars. Boars were divided into six classes according to their age when the ejaculate was taken $(10-13,14-17,18-21,22-25$, 
26-29 and $\geq 30$ months). Semen samples were analyzed during four seasons of a year (spring, summer, autumn, winter). The intensity of the use of boars (I) was observed as the influence of groups (classes) of the interval between two successful collections ( $\leq 5,6,7,8,9-10,11-13,14-21$ days). Ejaculates from boars that were preceded with the interval between two consecutive successful collections of 3 and 4 days, because of the small number, were attached to the group (class) of $\leq 5$ days.

Data analysis was performed using the GLM procedure using the statistical package SAS 9.1.3 (SAS Inst. Inc., 2002-2003). The following statistical model was used:

$$
\mathrm{Y}_{\mathrm{ijk} k \mathrm{~m}}=\mu+\mathrm{B}_{\mathrm{i}}+\mathrm{A}_{\mathrm{j}}+\mathrm{S}_{\mathrm{k}}+\mathrm{I}_{1}+\varepsilon_{i j k l m}
$$

where: $Y_{\mathrm{ijklm}}$ - observed sperm property, $\mu$ - general population average, $\mathrm{Bi}$ - the effect of the boar $(i=1,2,3, \ldots, 6), A_{j}$ - the effect of boar age class $(j=1,2,3, \ldots, 6), S_{k}-$ the effect of season $(\mathrm{k}=1,2,3,4), \mathrm{I}_{\mathrm{l}}$ the effect of utilization intensity $(1=1,2,3, \ldots, 7)$ and $\varepsilon_{i j k l m}$ - random error. Testing (comparison) of Least Square Means (LSMeans) values was done using t- test.

\section{Results and discussion}

The mean age of studied boars was 655.93 days or 21.86 months (Table 1). The mean volume of ejaculates was $178.94 \mathrm{ml}$, sperm motility was $90.35 \%$. The interval between successive collections of boars ranged from 3 to 21 days, or in average 9.37 days.

Table 1. The average values $(\bar{X})$ and variability of studied properties of boar ejaculates

\begin{tabular}{|l|c|c|c|c|c|}
\hline \multicolumn{1}{|c|}{ Variable } & $\mathrm{NE}$ & $\bar{X}$ & $\mathrm{SD}$ & Min & Max \\
& & & & & \\
\hline Volume of ejaculates (VOL, ml) & 274 & 178.94 & 51.30 & 50 & 300 \\
\hline Motility (MO, \%) & 274 & 90.35 & 5.69 & 70 & 100 \\
\hline Interval between successive collections (I, day) & 274 & 9.37 & 3.79 & 3 & 21 \\
\hline Age of boars of the collection (A, day) & 274 & 655.93 & 239.33 & 289 & 1628 \\
\hline
\end{tabular}

NE- Number of ejaculates; SD- Standard Deviations; Min- Minimum; Max- Maximum

The average value for VOL of ejaculate in this study was lower compared to the research by Kunowska-Slósarz and Makowska (2011) 178.94 compared to $255.25 \mathrm{ml}$ ) for the same breed of boars. In regard to MO, the average value in the present paper was higher $(+11.20 \%)$ compared to the value obtained by aforementioned authors. The high average value of MO in this study was the result of exclusion of ejaculates with value below $70 \%$, and subjectivity in the visual assessment of sperm motility in the ejaculate. In the study by Sutkevičiené and 
Žilinkas (2004), the average age of the boars was $18.79 \pm 5.59$ months, with an average volume of ejaculate from $261.60 \pm 134.25 \mathrm{ml}$, and the percentage of subjective sperm motility of $71.49 \pm 6.42 \%$.

The impact of factors on varying of sperm properties is presented in Table 2. Calculated coefficients of determination indicated that the variability of the VOL compared to the MO, can be explained to a greater extent as influenced by factors observed.

Both properties of sperm varied under the influence of boars $(B, p<0.001)$, indicating a need for individual control of each of boars used for artificial insemination. Unlike the MO whose variability was not influenced by other observed factors, the VOL varied under the influence of age (A, $\mathrm{p}<0.001)$, and the season ( $S, p<0.01)$. The intensity of use of boars (I, $p>0.05$ ) did not significantly affect the variability of VOL and MO in sperm.

Table 2. Effect of variables included in the model

\begin{tabular}{|c|c|c|c|c|}
\hline \multirow{3}{*}{ Variable } & \multicolumn{4}{|c|}{ Semen traits } \\
\hline & \multicolumn{2}{|c|}{ VOL } & \multicolumn{2}{|c|}{ MO } \\
\hline & $\mathrm{p}$ & $\mathrm{R}^{2}$ & $\mathrm{p}$ & $\mathrm{R}^{2}$ \\
\hline Boars (B) & *** & \multirow{4}{*}{0.361} & *** & \multirow{4}{*}{0.143} \\
\hline Classes of age of boars (A) & $* * *$ & & ns & \\
\hline Season $(\mathrm{S})$ & $* *$ & & ns & \\
\hline Interval between successive collections (I) & $\mathrm{ns}$ & & $\mathrm{ns}$ & \\
\hline
\end{tabular}

VOL- Volume of ejaculates; MO- Motility; $\mathrm{R}^{2}$ - Coefficient of determination;

$*_{-}$- $<0.01 ; * * *_{-} \mathrm{p}<0.001$

The results of this study pertaining to the significance of the factors included in the model are partly consistent with the research of Smital (2010) in which all the studied factors (breed-center, year, month, and year x month, boar age, interval between collections and boars) have influenced $(p<0.001)$ all the analyzed properties of the sperm.

Both studied properties of sperm varied between boars (Table 3). Boar number 4 had the highest VOL, and the difference compared to the boars number 2 and 3, was 41.57 and $31.57 \mathrm{ml}$, respectively $(\mathrm{p}<0.001)$. The difference between boars with the highest and lowest MO (boars 6 and 5 ) was $8.86 \%(\mathrm{p}<0.01)$. Boar 5 had lower average sperm motility than boars 4 and $2(-8.38$ and $-8.69 \%)$. The differences established between the mean values of MO between stated boars were highly statistically significant $(\mathrm{p}<0.01)$. 
Table 3. Effect of boars on semen properties

\begin{tabular}{|c|c|c|}
\hline \multirow{2}{*}{ Boars } & \multicolumn{2}{|c|}{ LSMeans \pm SE } \\
\cline { 2 - 3 } & VOL $(\mathrm{ml})$ & MO (\%) \\
\hline 1 & $169.03 \pm 9.31$ & $90.19 \pm 1.20$ \\
\hline 2 & $156.79 \pm 7.06^{\mathrm{A}}$ & $91.69 \pm 0.91^{\mathrm{Aa}}$ \\
\hline 3 & $166.79 \pm 5.05^{\mathrm{A}}$ & $88.71 \pm 0.65^{\mathrm{a}}$ \\
\hline 4 & $198.36 \pm 4.63^{\mathrm{B}}$ & $91.38 \pm 0.60^{\mathrm{b}} \mathrm{Aa}$ \\
\hline 5 & $170.42 \pm 16.29$ & $83.00 \pm 2.09^{\mathrm{Bb}}$ \\
\hline 6 & $179.81 \pm 8.09$ & $91.86 \pm 1.04^{\mathrm{Aa}}$ \\
\hline
\end{tabular}

VOL- Volume of ejaculates; MO- Motility; a, b- $<<0.05$; Aa, Bb- $<<0.01 ; A, B-p<0.001$

If both properties are observed, the highest number of doses with an average motility of spermatozoa of $91.38 \%$ was possible to produce from ejaculates taken from boar 4 .

The lowest VOL of ejaculate (Table 4) was at the age of boars of 10-13 months (class 1). Lower mean values of the volume of ejaculate (from 134.59 to $169.97 \mathrm{ml}$ ) were observed in age classes 1 to 3 (boars at the age of 10 to 21 months), higher values (from 191.04 to $197.29 \mathrm{ml}$ ) were observed in the class of 4 to 6 (boars at the age of over 21 months).

The main reason for the increase of VOL with the age of boars is increase in the size and mass of the testes, causing increase in the production of sperm. According Kanokwan (2011) one of the reasons for increasing sperm production from a biological point of view is the increase in the number of Sertoli cells in the testes. According to Ford et al. (2006) the primary factor in daily sperm production is the number of Sertoli cells, which is associated with the testicular mass. The highest VOL was determined in boars at the age of 26 to 29 months, and the difference compared to the boars aged $10-13$ months was $62.70 \mathrm{ml}(\mathrm{p}<0.001)$. Boars of age group 2 had lower average volume of ejaculate compared to boars in group $4(-36.66 \mathrm{ml}, \mathrm{p}<0.05)$, group $6(-39.55 \mathrm{ml}, \mathrm{p}<0.05)$ and group $5(-42.91 \mathrm{ml}$, $\mathrm{p}<0.001)$. No statistically significant differences were established in VOL between boars older than 17 months (from class 3 to 6). In populations of pigs which are in a program of continuous selection and breeding, due to high selection pressure, boars are commonly used in the reproduction for 6-8 months, so they do not achieve maximum VOL values. In regard to $\mathrm{MO}$, there were no statistically significant differences $(p>0.05)$ in mean values between the age groups of boars. 
Table 4. Least Square Means values and differences between classes of age of the boars

\begin{tabular}{|c|c|c|c|}
\hline \multicolumn{2}{|c|}{ Age of the boars } & \multicolumn{2}{|c|}{ LSMeans \pm SE } \\
\hline Classes & Month & VOL $(\mathrm{ml})$ & MO (\%) \\
\hline 1 & $10-13$ & $134.59 \pm 10.25^{\mathrm{A}}$ & $89.92 \pm 1.32$ \\
\hline 2 & $14-17$ & $154.38 \pm 8.34^{\mathrm{a}, \mathrm{AA}}$ & $90.46 \pm 1.08$ \\
\hline 3 & $18-21$ & $169.97 \pm 7.05$ & $87.87 \pm 0.91$ \\
\hline 4 & $22-25$ & $191.04 \pm 7.30^{\mathrm{B}, \mathrm{b}}$ & $88.27 \pm 0.94$ \\
\hline 5 & $26-29$ & $197.29 \pm 8.53^{\mathrm{B}, \mathrm{BB}}$ & $89.54 \pm 1.10$ \\
\hline 6 & $\geq 30$ & $193.93 \pm 7.79^{\mathrm{B}, \mathrm{b}}$ & $90.77 \pm 1.00$ \\
\hline
\end{tabular}

VOL- Volume of ejaculates; MO- Motility; a, b- p<0.05; A, B i AA, BB- $<<0.001$

There is a tendency of increase of ejaculate volume with increasing age of boars. Similar conclusions have been made in the study by Stančić et al.(2003), Banaszewska and Kondracki (2012). Ejaculate volume increases until the age of about two years, and remains more or less constant (Wolf and Smital, 2009a; Wolf and Smital, 2009b), so that our research was in accordance with the research of these authors, since the higher VOL values were observed in boars older than 21 months. The results of this study are consistent with research results of Smital (2009), in which an increase of sperm parameters with age boars was observed, but achieving of the maximum values of the parameters of boar semen was at the age of 3.5 years.

The results of the present study pertaining to the effect of boar age on MO are consistent with the research of Šerniené et al. (2002) in which the differences between the age groups of boars were recorded, but not significant.

The effect of the season on the variability of VOL was highly significant (Table 2, $\mathrm{p}<0.01$ ), and LSMean values during different seasons, according the analyzed properties of the sperm, are presented in Table 5 .

The highest VOL was in the summer period $(187.34 \pm 7.75 \mathrm{ml})$, and lowest in the winter period $(155.19 \pm 6.37 \mathrm{ml})$. The highest difference in mean values was recorded between these two annual seasons $(32.15 \mathrm{ml} ; \mathrm{p}<0.01)$. In winter the volume of ejaculates was lower than in the autumn $(-26.57 \mathrm{ml})$ and observed difference was statistically significant $(p<0.05)$. Low value of VOL during winter may be due to inadequate housing conditions caused by low temperatures. The lowest MO was during the winter period $(88.58 \%)$, but when it comes to the variability of these properties, the differences between seasons were not significant.

Table 5. Effect of season on variability of the semen traits

\begin{tabular}{|c|c|c|}
\hline \multirow{2}{*}{ Season } & \multicolumn{2}{|c|}{ LSMeans \pm SE } \\
\cline { 2 - 3 } & VOL $(\mathrm{ml})$ & MO $(\%)$ \\
\hline Spring & $169.85 \pm 6.33$ & $89.50 \pm 0.81$ \\
\hline Summer & $187.34 \pm 7.75^{\mathrm{Aa}}$ & $89.10 \pm 1.00$ \\
\hline Autumn & $181.76 \pm 7.29^{\mathrm{a}}$ & $90.71 \pm 0.94$ \\
\hline Winter & $155.19 \pm 6.37^{\mathrm{Bb}, \mathrm{b}}$ & $88.58 \pm 0.82$ \\
\hline
\end{tabular}

VOL- Volume of ejaculates; MO- Motility; a, b- $<<0.05$; $\mathrm{Aa}, \mathrm{Bb}-\mathrm{p}<0.01$ 
The results of this study, which related to the value of the VOL in the spring period $(169.85 \mathrm{ml})$, and which was below the annual average $(178.94 \mathrm{ml})$, are partially similar to studies by Okere et al. (2005), Kondracki et al. (2009), Wolf and Smital (2009a), who established, in the spring, the lowest volume of ejaculate in the studied breeds. Partial similarity is also with the results of research Kunowska-Slósarz and Makowska (2011), given that in the study of the authors in the period January-June VOL values determined were below the annual average, and above average values from August to December.

In Table 6, LSMean values are presented according to groups (classes) of the interval between two successful collections. There were differences between the groups (classes) but they were not significant $(\mathrm{p}>0.05)$. A small number of ejaculate that were preceded by the interval between two consecutive successful collections of three or four days contributed to a reduction in the variability of sperm properties influenced by this factor.

Table 6. Effect of the interval between successive collections (I)

\begin{tabular}{|c|c|c|}
\hline \multirow{2}{*}{ Interval between successive collections (I, day) } & \multicolumn{2}{|c|}{ LSMeans \pm SE } \\
\cline { 2 - 3 } & VOL $(\mathrm{ml})$ & MO (\%) \\
\hline$\leq 5$ & $159.65 \pm 8.80$ & $88.34 \pm 1.13$ \\
\hline 6 & $182.30 \pm 7.88$ & $89.80 \pm 1.01$ \\
\hline 7 & $173.91 \pm 8.37$ & $89.16 \pm 1.07$ \\
\hline 8 & $175.94 \pm 7.15$ & $89.23 \pm 0.92$ \\
\hline $9-10$ & $169.47 \pm 6.26$ & $89.91 \pm 0.80$ \\
\hline $11-13$ & $173.97 \pm 7.05$ & $89.66 \pm 0.91$ \\
\hline $14-21$ & $179.50 \pm 7.67$ & $90.21 \pm 0.99$ \\
\hline
\end{tabular}

VOL- Volume of ejaculates; MO- Motility

Contrary to the present study, in the research carried out by Frangež et al. (2005), the differences in the characteristics between the sperm of different frequencies of use of boars were established. The research by Wolf and Smital (2009a) has shown small increase in ejaculate VOL with extension of I from two to seven days, while for longer intervals changes were insignificant, and small changes have been observed when it comes to the variability of MO.

\section{Conclusion}

Variability in the ejaculate VOL compared to the MO can be largely explained by the influence of the analyzed factors .

Ejaculate volume varied under the influence of boars $(B, p<0.001)$, age (A, $\mathrm{p}<0.001)$, and the season $(\mathrm{S}, \mathrm{p}<0.01)$. MO variability was only under a significant effect of boars (B, $p<0.001)$. The intensity of use of boars (I, p >0.05) in this study did not show a significant effect on the studied properties of semen. 
Variability between boars in the studied traits of sperm is high, indicating the need for individual control of each of boars used for artificial insemination.

There is a tendency of VOL increase with the age of boars. No statistically significant differences were determined between VOL values of boars older than 17 months (from class 3 to 6 ). However, given that in the selected population of pigs, boars are used in the reproduction for 6 to 8 months, this tendency has no practical significance.

Given that there are differences in the VOL according to seasons, it is necessary to provide boars during the year with the adequate housing conditions and optimum microclimate parameters.

\section{Acknowledgements}

Research was financed by the Ministry of Education, Science and Technological Development of Republic of Serbia, project TR 31081.

\section{Varijabilnost volumena ejakulata i pokretljivosti spermatozoida u zavisnosti od starosti i intenziteta korišćenja nerasta}

R. Savić, M. Petrović, D. Radojković, Č. Radović, N. Parunović, M. Pušić, R. Radišić

\section{Rezime}

Osnovni cilj istraživanja bio je da se oceni uticaj starosti (A) i intenziteta korišćenja nerasta (I) na fenotipsku varijabilnost volumena ejakulata (VOL) i pokretljivosti spermatozoida (MO). Istraživanjem je bilo obuhvaćeno 274 ejakulata nerasta rase veliki jorkšir (LW). Nerasti su prema starosti kada je uzet ejakulat podeljeni u šest klasa (10-13, 14-17, 18-21, 22-25, 26-29 i $\geq 30$ meseci). Ejakulati su analizirani tokom četiri godišnje sezone (proleće, leto, jesen, zima). Intenzitet korišćenja nerasta posmatran je kao uticaj grupe (klase) intervala između dva uspešna skoka (I; $\leq 5,6,7,8,9-10,11-13,14-21$ dan). Obrada podataka izvršena primenom GLM procedure uz pomoć statističkog paketa SAS 9.1.3 (SAS Inst. Inc., 2002-2003).

Prosečne vrednosti VOL, MO, I, A bile su: 178,94 ml, 90,35\%, 9,37 dana i 655,93 dana. Uticaj nerasta na obe ispitivane osobine sperme bio je vrlo visoko značajan $(\mathrm{p}<0,001)$. Volumen ejakulata varirao je pod uticajem starosti nerasta $(p<0,001)$ i sezone $(p<0,01)$. Uticaj I na VOL i MO nije bio značajan $(p>0,05)$. Osobine VOL i MO varirale su $(\mathrm{p}<0,001)$ između nerasta što ukazuju na potrebu 
individualne kontrole svakog nerasta koji se koristi za veštačko osemenjavanje. Najveći VOL utvrđen je kod nerasta pri uzrastu od 26 do 29 meseci, a razlika u odnosu na neraste uzrasta 10-13 meseci bila je $62,70 \mathrm{ml}(\mathrm{p}<0,001)$. Nisu ustanovljene statistički značajne razlike VOL izmedju nerasta starijih od 17 meseci (od klase 3 do 6). Izmedju zimskog i letnjeg perioda godine utvrdjena je najveća razlika srednjih vrednosti VOL $(32,15 \mathrm{ml} ; \mathrm{p}<0,01)$. U zimskom periodu volumen ejakulata nerasta bio je manji nego u toku jeseni $(-26,57 \mathrm{ml})$ i utvrdjena razlika je bila statistički značajna $(\mathrm{p}<0,05)$.

\section{References}

BANASZEWSKA D., KONDRACKI S. (2012): An assessment of the breeding maturity of insemination boars based on ejaculate quality changes. Folia Biologica (Kraków), 60, 3-4, 151-162.

FEITSMA H. (2009): Artificial insemination in pigs, research and developments in the Netherlands, a review. Acta scientiae veterinariae, 37, 1, 61-71.

FORD J.J., McCOARD S.A., WISE T.H., LUNSTRA D.D., ROHRER G.A. (2006): Genetic variation in sperm production. Control of pig reproduction VII: Proceedings of the Seventh International Conference on Pig Reproduction, Kerkrade, the Netherlands, June 2005/ edited by C.J. Ashworth and R.R. Kraaling, Nottingham, U. K.: Nottingham University Press, 99-112.

FRANGEŽ R., GIDER T., KOSEC M. (2005): Frequency of boar ejaculate collection and its influence on semen quality, pregnancy rate and litter size. Acta vet. Brno, 74, 265-273.

KANOKWAN K. (2011): Association and expression study of CD9, PLCz and COX-2 as candidate genes to improve boar sperm quality and fertility traits. Institut für Tierwissensechaften, Abt. Tierzucht und Tierhaltung der Rheinischen Friedrich-Wilhelms- Universität Bonn. Inaugural-Dissertation.

KONDRACKI S., WYSOKIŃSKA A., KOWALEWSKI D., MUCZYŃSKA E., ADAMIAK A. (2009): Season's influence on the properties of male domestic pig semen. Rozprawy naukowe Pope John Paul II State School of Higher Vocational Education in Biała Podlaska, 3, 177-187.

KUNOWSKA-SLÓSARZ M., MAKOWSKA A. (2011): Effect of breed and season on the boar's semen characteristics. Annals of Warsaw University of life sciences- SGGW, Animal Science, 49, 77-86.

OKERE C., JOSEPH A., EZEKWE M. (2005): Seasonal and genotype variations in libido, semen production and quality in artificial insemination boars. Journal of animal and veterinary advances, $4,10,885-888$.

SAS INST. INC. (2002-2003): The SAS System for Windows, Cary, NC.

SMITAL J. (2009): Effects influencing boar semen. Animal reproduction, 110, 3, 335-346. (abstract) 
SMITAL J. (2010): Comparison of environmental variations in boar semen characteristics of six breeds and their crossbreds over an eight-year period. Research in pig breeding, 4, 1, 26-32.

STANČIĆ B., GAGRČIN M., RADOVIĆ I. (2003): Uticaj godišnje sezone, rase i starosti nerastova na kvalitet sperme (1. Nativna sperma). Biotechnology in Animal Husbandry, 19, 1-2, 17-23.

SUTKEVIČIENÉ N., ŽILINKAS H. (2004): Sperm morphology and fertility in artificial insemination boars. Veterinarija ir zootechnika, 26, 48, 11-13.

ŠERNIENÉ L., RIŠKEVIČIENÉ V., BANYS A., ŽILINKAS H. (2002): Effects of age, and season on sperm qualitative parameters in Lithuanian white and Pietrain boars. Veterinarija ir zootechnika, 17 (39).

WOLF J., SMITAL J. (2009a): Effects in genetic evaluation for semen traits in Czech Large White and Czech Landrace boars. Czech J. Anim. Sci., 54, 8, 349358.

WOLF J., SMITAL J. (2009b): Quantification of factors affecting semen traits in artificial insemination boars from animal model analyses. Journal of animal science, $87,1620-1627$.

Received 22 July 2013; accepted for publication 28 November 2013 